\title{
Malay Epic and Historiography Literature Students' Perception Towards Interactive Online Interaction
}

\author{
Salmah J. N. Muhammad ${ }^{1}$, Che N. C. Puteh ${ }^{1} \&$ Normaliza Abd Rahim ${ }^{1}$ \\ ${ }^{1}$ Faculty of Modern Languages and Communication, Universiti Putra Malaysia, Selangor, Malaysia \\ Correspondence: Salmah J. N. Muhammad, Department of Malay Language, Faculty of Modern Languages and \\ Communication, Universiti Putra Malaysia, 43400 UPM Serdang, Selangor, Malaysia. Tel: 603-8946-8676. \\ E-mail: salmahjan@upm.edu.my
}

Received: February 19, 2019

Accepted: March 15, 2019 Online Published: April 30, 2019

doi:10.5539/ass.v15n5p23

URL: https://doi.org/10.5539/ass.v15n5p23

\begin{abstract}
Technology is a need among modern community that ensures new knowledge and can be shared and utilized together. In teaching and learning, technology usage can be considered as a tool that can improve students' cognitive, psychomotor and effective, also can interconnect with each other. Without technology, the learning world can be classified as a backward era. Therefore, through the interactive connection, learning can be more interesting and effective. Thus, the effectiveness of students' needs will be measured either interactive connection that attracts students' interest or vice-versa. Therefore, the objectives of the study are to determine the response towards online teaching interactive, also to analize and summarize UPM students online interactive connection by using the Technology Acceptance Model (TAM). This research applied online questionnaire by using the Monkey Survey website. About 94 Univeriti Putra Malaysia students from BBK 3311 Malay Epic and Historiography Literature course were choosen as research samples. The results of the study showed that majority of the samples are satisfied with the technology interactive method that had been introduced in this subject through Putramooc Malay Art platform. It is hoped that this research can help to identify the technology interactive connection through the most dominant multimedia and can be applied by the parties involved.
\end{abstract}

Keywords: technology, interactivity, MonkeySurvey, Technology Accaptence Model (TAM)

\section{Introduction}

Today's interactive online interaction can attract the society's interest, no matter young or old. Through interactive interaction, the learning process can be carried out with different methods and interesting atmosphere. Among the ways in which learning is gained through online is interactivity. In contributing knowledge in learning, interactivity is very important to ensure learning becomes active and interesting by taking proactive involvement into account. In addition, this kind of learning is said to be interesting as each student will be exposed with interactive combined with multimedia. Therefore, the use of computers with the existence of video, animation, graphics, texts and much more causes the field of knowledge to be more attractive and evolving. According to Normaliza Abd Rahim, Awang Azman Awang Pawi \& Nik Rafidah Nik Muhammad Affendi (2018) and Normaliza Abd Rahim (2014), today's technological developments can benefit and even be accepted as one of the medium of knowledge sharing with audiences. Additionally, this intake will be included with different system chains. The development of this technology is seen to facilitate the work of the people who foresee the importance of the new technology towards their wellbeing.

A study by Sukhminder Kaur, Goh Wei Wei \& Kng Pei Gee (2018) examines online learning that can change the perceptions of academicians. Online learning is often applied compared to the traditional methods. Massive Open Online Courses (MOOCs) is among the famous open online learning. MOOCs are able to provide certain knowledge and input according to the subjects specified by the online provider. The concept of openness in learning is increasingly accepted among the society. This course is an easy-to-access online that has some basic rules that can provide a unique learning goal. This basic rule will provide students with the knowledge of the present and the diverse skills that can boost the performance of students who want to succeed. The study by Sukhminder Kaur, Goh Wei Wei \& Kng Pei Gee (2018) uses the theory of Theory Acceptance Model (TAM) introduced by Davis (1989). This theory focuses on how one accepts the exposure to technology. The results of the study show that MOOC has a positive effect on the learning process, but it can be achieved fully by the 
student. The results of this study are similar to the results of Siti Zulaidah Salsidu, Mohamed Nor Azhari Azman \& Mai Shihah Abdullah (2017) where the rapid development of education has further enhanced the level of computing information and technology within the country. Technology that is diversified with interactive multimedia such as video, moving text, audio, and liquid crystal display and so on can attract students to continue to understand the subjects taught. The theory used in this study is the Multiple Intelligence Theory pioneered by Gardner (2003). This theory presents the various intelligences that are the focuses of humanity among them are musical intelligence, math, and visual space. Therefore, the use of interactive multimedia in learning is seen as making it the best medium to present a subject effectively. The results of the study by Siti Zulaidah Salsidu, Mohamed Nor Azhari Azman \& Mai Shihah Abdullah (2017) show that the use of interactive multimedia is seen to be able to attract students in a heavy subject. Additionally, it is able to rapidly improve the student's cognitive and psychomotor skills in any area that they are involved in.

A study by Endang Fatmawati (2015) looks at the existence of online technology for employees and library users. OPAC technology was introduced to solve problems related to this. Furthermore, this system openly contributes to a useful source of knowledge or information. This will be done by using a separate access code so that it can be opened and widely used.This study was conducted using TAM theory. This theory is used to ensure research can be done on the attitude of the user or their behavior that uses the library. The results of the study show that employees and library users can utilize the best available facilities. Furthermore, the benefits of this technology are also supported by Asri Mulyani \& Dede Kurniadi (2015). The study by Asri Mulyani \& Dede Kurniadi (2015) using Student Information Terminal (S-IT) also uses TAM. This study involved 200 samples of Information and Computer Management Academy (AMIK), Garut, Indonesia to obtain research related reactions. This study uses the Structural Equation Model (SEM) and the Analysis of Moment Structure (AMOS) program. SEM is used to solve the multilevel investigation problem. This study clearly shows that the ease of academic access can provide new input to the students and facilitate their learning. In addition, Ribka Armanda (2015) agrees with the study of Asri Mulyani \& Dede Kurniadi (2015) and has been doing research to identify progress in technology is capable of being fully utilized in accounting. This research also uses the TAM method that is able to provide feedback to researchers in the development of the business and the ability of employees to work in tandem with advanced technology conditions according to their system. The results of the study by Ribka Armanda (2015) found that the theory used was very good and fulfilled the standard of activity conducted by researchers. In addition, the management also supports when this technology is fully utilized by employees. The results of the study also show a positive result that is by generating positive outlines in this observation.

Fran Sayekti and Pulasna Putarta (2016) point out that new information or technology advancements can serve as a tool to gain success in developing informational world. Therefore, it is very important for a research to know whether this technology is accepted or not by its users. This can help users to use the best technology possible for the goal of an organization to achieve. In this study, the TAM method has been used by researchers to achieve the objectives of the study with the acceptance of the regional financial information system study. Furthermore, this study will look at the response about technology reformation is followed by its users or otherwise. This study has shown that new technology such as the Financial Information System for Local Government (SIPKD) will be adequately utilized by consumers if they understand how to use them. A legislative amendment will be made to make it compulsory if it is used continuously and beneficial to all. This study has achieved its own goal when the study finds that advances in technology have a positive impact on its use. Subsequently, the same opinion was raised by Aslina Saad \& Ermie Dharlya Daud (2016) where Internet technology is an infrastructure that is able to manage affairs and administration efficiently. As such, the Ministry of Education Malaysia (MOE) has taken steps to realize the goal of a better and steady information management. This can be done in the way of Online Teacher (GDM) which is a technology capable of managing student information online. GDM seeks to ensure that teachers are able to coordinate student information efficiently and accurately. To get information on whether this technology provides positive or negative responses then the TAM theory has been used to know about the capabilities of GDM technology. Technology is a communications field that is capable of detecting social conditions and user acceptance whether they are capable of using the technology well or not. The TAM theory used will compare its capabilities that achieve the goals and objectives set by the government. According to Normaliza Abd Rahim (2014; 2013), Noraien Mansor \& Normaliza Abd Rahim (2017a; 2017b; 2017c; 2017d) and Adenan Ayob (2017), the development of technology in learning benefits many communities, especially students. Teaching and learning are more interesting with the presence of interactivity among students by using material through the website. Adenan Ayob (2017) sees the difference between learning using interactive websites and conventional learning methods. The advanced development in the field of education is a drastic change. However, these technologies will unify new sciences with humans, things and so on. This demonstrates that this interactive provides infrastructure and critical and creative thinking advantages and is used to give a 
clear understanding to the children. As a result, this study found that interactive methods can save time for the purpose of reading the material. In addition, information related to learning is also accessible to the students. Interactive learning through this website is seen to enhance student knowledge in their learning. They can even increase their knowledge without waiting for reading activities done in the classroom. This can raise student learning in line with the wishes of the Ministry of Education today. Furthermore, this is also supported by Norazilawati Abdullah, Nik Azmah Nik Yusuf, Noraini Mohamed Noh \& Mohd Nazir Md Zabit (2017) that emphasis on interactive software capability of enhancing the students' skills in science subjects. The software is a software that is capable of providing a clear understanding of the subject of science to the students. Furthermore, the results of the study find that it is highly accurate that interactive technology is capable of supporting various aspects of teaching and learning. In fact, it can be seen that the students' mastery of the subject is also outstanding. This interactive technology is seen to be able to help students understand exactly what they need to learn in selected subjects.

Based on the above studies, this study will identify students' responses to online teaching interactivity. Furthermore, this study will also analyze and formulate interactivity on online university students.

\section{Method}

This study uses quantitative methods to obtain valid information to further enhance the results of this study. This study involves selected Universiti Putra Malaysia students by using Monkey Survey online technology to facilitate the data collection. The sample of the study was a total of 94 students in Universiti Putra Malaysia (UPM) who took BBK3311 Malay Epic and Historiography Literature, aged between 21 to 30 years old. On the other hand, the gender of the study sample consisted of 73 females and 21 males. A set of questions entitled BBK3311 Student Interactive Interaction Assessment via the Malay Art PutraMooc Platform is provided for the purpose of this study. This article focuses on online courses that contain instructional interactivity to obtain real information about the 14 questions presented to the sample. Therefore, the 14 instruments selected are really necessary to ensure that this study can be steadily implemented. This instrument shows that the importance of the students for them to learn online (Schedule S1).

Table 1. List of Online Interactivity Interaction Percentage

\begin{tabular}{|c|c|c|c|c|c|}
\hline \multirow[b]{2}{*}{ ITEM } & \multicolumn{5}{|c|}{ PERCENTAGE } \\
\hline & $\begin{array}{l}\text { Strongly } \\
\text { Agree }\end{array}$ & Agree & Moderate & Disagree & $\begin{array}{l}\text { Strongly } \\
\text { Disagree }\end{array}$ \\
\hline $\begin{array}{l}\text { This online course provides the syllabus in line with the } \\
\text { curriculum formulated by Malaysia Ministry of Education }\end{array}$ & $60.49 \%$ & $33.33 \%$ & $6.17 \%$ & $0.00 \%$ & $0.00 \%$ \\
\hline $\begin{array}{l}\text { This Online Course Provides Teaching Objectives that is } \\
\text { Easily Accessible to Students' Intelligence Diversity }\end{array}$ & $62.96 \%$ & $28.40 \%$ & $8.64 \%$ & $0.00 \%$ & $0.00 \%$ \\
\hline $\begin{array}{l}\text { This Online Course Provides Teaching Content that Meets } \\
\text { the Specified Objective }\end{array}$ & $66.67 \%$ & $27.16 \%$ & $4.94 \%$ & $1.23 \%$ & $0.00 \%$ \\
\hline $\begin{array}{l}\text { This Online Course Prepares Teaching Content Related to } \\
\text { Student's Existing Knowledge }\end{array}$ & $61.73 \%$ & $30.86 \%$ & $6.17 \%$ & $1.23 \%$ & $0.00 \%$ \\
\hline $\begin{array}{l}\text { This Online Course Provides Facts and Concepts that is } \\
\text { Easily Understood by Students }\end{array}$ & $65.43 \%$ & $30.86 \%$ & $2.47 \%$ & $1.23 \%$ & $0.00 \%$ \\
\hline $\begin{array}{l}\text { This Online Course Has Sustainable Content and Well } \\
\text { Organized and Not Confusing. }\end{array}$ & $66.67 \%$ & $28.40 \%$ & $3.70 \%$ & $1.23 \%$ & $0.00 \%$ \\
\hline $\begin{array}{l}\text { This Teaching Presentation and Strategy Matches the } \\
\text { Diversity of Students' Abilities }\end{array}$ & $61.73 \%$ & $29.63 \%$ & $8.64 \%$ & $0.00 \%$ & $0.00 \%$ \\
\hline $\begin{array}{l}\text { Teaching Strategies (simulations, tutorials, drills and } \\
\text { games) in this course are relevant to the topic taught. }\end{array}$ & $65.43 \%$ & $30.86 \%$ & $3.70 \%$ & $0.00 \%$ & $0.00 \%$ \\
\hline $\begin{array}{l}\text { This Online Course Provides Training That Helps } \\
\text { Strengthen the Understanding of Students' Concepts }\end{array}$ & $66.67 \%$ & $27.16 \%$ & $6.17 \%$ & $0.00 \%$ & $0.00 \%$ \\
\hline $\begin{array}{l}\text { This Online Course Provides An Opportunity to Repeat } \\
\text { Exercises }\end{array}$ & $66.67 \%$ & $27.16 \%$ & $4.94 \%$ & $1.23 \%$ & $0.00 \%$ \\
\hline This Online Course Provides Feedback That Ensures & $61.73 \%$ & $29.63 \%$ & $8.64 \%$ & $0.00 \%$ & $0.00 \%$ \\
\hline
\end{tabular}


Students Learn From Mistakes

This Online Course Provides Activity and Problem that is Teaching The Students Problem Solving Skills.

This Online Course Helps Facilitate R \& D Process

$\begin{array}{rrrrr}62.96 \% & 27.16 \% & 9.88 \% & 0.00 \% & 0.00 \% \\ 69.14 \% & 23.46 \% & 7.41 \% & 0.00 \% & 0.00 \% \\ 62.96 \% & 30.86 \% & 6.17 \% & 0.00 \% & 0.00 \%\end{array}$

This Online Course Can Be Used by Students for Self-Learning.

This study is an online study conducted using the data from Universiti Putra Malaysia students who study online for the subject of BBK3311 Malay Historiography and Epic Literature. This online study was conducted for only 15 minutes to wait for the students to fulfill the questions raised in the website. The quantitative study used is the best way to collect the accurate data.

The theory used to fulfill this research is the Technology Acceptance Model (TAM) theory spearheaded by Fred Davis in 1989. TAM is a theory used to understand information systems that are communication systems used in a community organization. This theory explains a lot on how technology users use technology and receive technology in their lives. According to Khairani Ratnasari Siregar (2011), TAM's theory has two stakes, whether technology users will benefit from technology and what they think about the technology they've been using. This is because in today's modern era, there are too many new technologies that meet the needs of the community so sometimes it is unattainable for consumers. Agus Ana Widiatmika \& Dana Indra Sensuse (2015: 81) explain that technology is the largest contributor to new information, communication and broad technologies of reach.

\section{Results}

\subsection{This Online Course Contains This Teaching Interactivity}

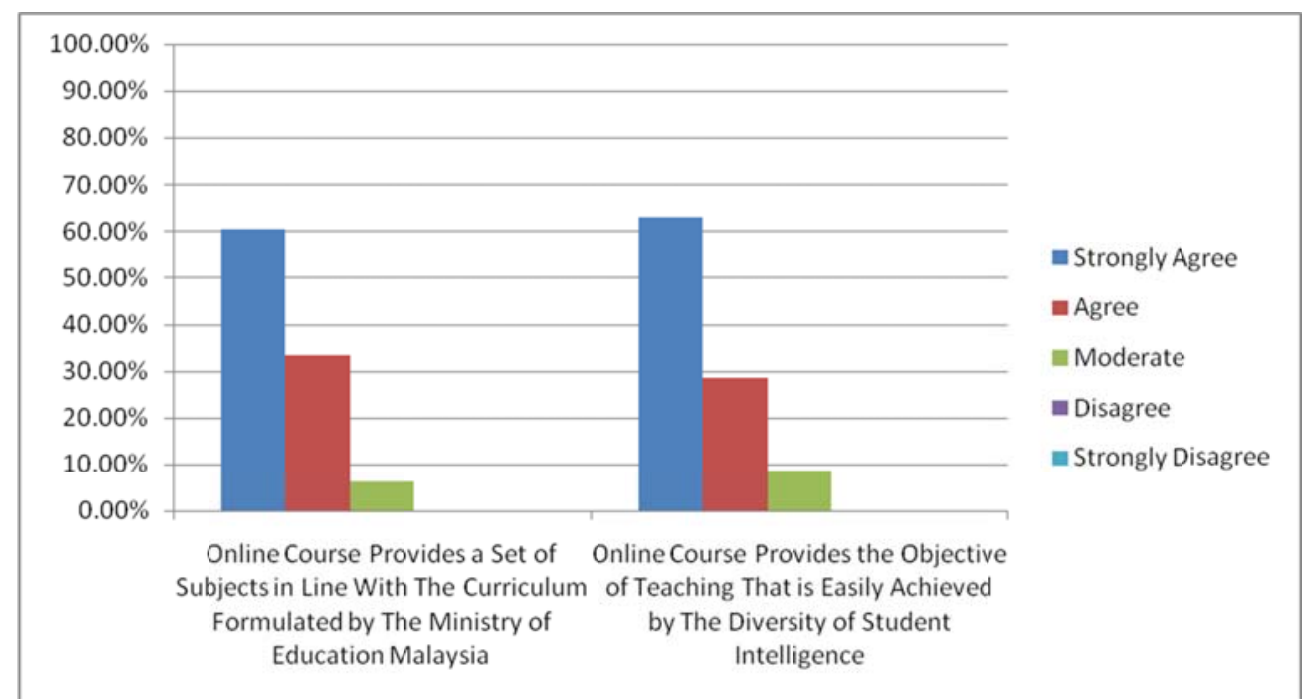

Figure 1. This online course contains this teaching interactivity for item 1 and item 2

Figure 1 shows this online course contains teaching interactivity for items 1 and 2 . Item 1 , online course provides a set of subjects in line with the curriculum formulated by the Ministry of Education Malaysia which shows that 49 students $(60.49 \%)$ choose to strongly agree, while 27 students $(33.33 \%)$ choose to agree. Meanwhile, to disagree and strongly disagree, there is no vote from the students. Additionally, a total of 5 students $(6.17 \%)$ chose moderate for this question. The results show that students are more likely to use interactive buttons in giving feedback. This is likely because the preparation of the subject through online is in line with the curriculum from the Ministry of Education Malaysia. Hence, students are more likely to continue with online learning.

Next, item 2 above shows this online course provides the objective of teaching that is easily achieved by the diversity of student intelligence. Item 2 shows that a total of 51 students $(62.96 \%)$ are strongly agree and 23 students $(28.40 \%)$ agree. Meanwhile, to disagree and strongly disagree, there is no vote from the students. Next, a total of 7 students $(8.64 \%)$ pressed the moderate button. The above results show that students are happy when they can understand what is being taught via online. A simple teaching method makes it easier for students to understand. Hence, students will be more focused on online teaching as it is easier. 


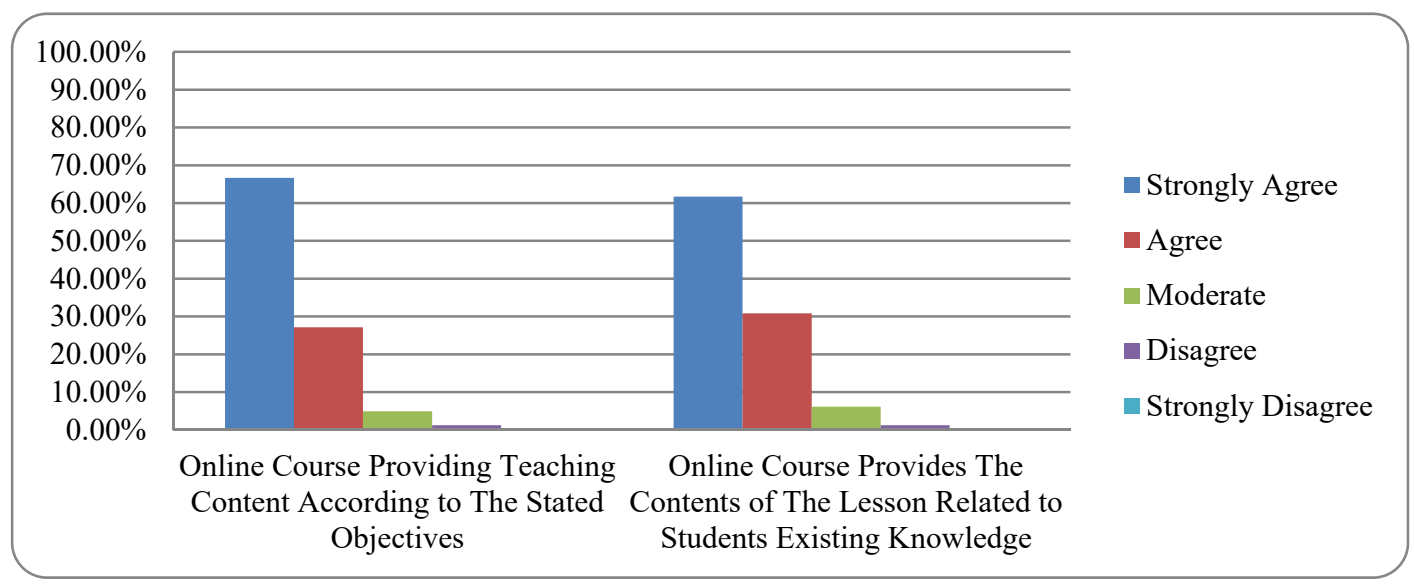

Figure 2. This online course contains this teaching interactivity for item 3 and item 4

Figure 2 above shows two items namely item 3 titled this online course providing teaching content according to the stated objectives and item 4 titled this online course provides the contents of the lesson related to students existing knowledge. Therefore, the item 3 graph shows that 54 students $(66.67 \%)$ strongly agree with the statement and 22 students $(27.16 \%)$ agree with this statement. There were no students who strongly disagree and 1 student $(1.23 \%)$ disagrees. Meanwhile, a total of 4 students $(4.94 \%)$ who pressed the moderate button. The above results show that, there are disagreements between students on items 3 and 4 . Therefore, it is possible that the teaching syllabus does not meet the objectives set by the instructors. The justification is that improvement needs to be done to attract students to achieve the objectives.

In addition, item 4, the online course provides the contents of the lesson related to the existing knowledge of a total of 50 students $(61.73 \%)$ who strongly agree and 25 students $(30.86 \%)$ agree. Meanwhile, no student strongly disagrees and 1 student $(1.23 \%)$ disagrees. The justification is that this teaching activity shows the content contained in the teaching is parallel to the general knowledge of the students. It can be seen that many students have extensive knowledge. However, the reform of teaching should be done because there are students who disagree with this statement.

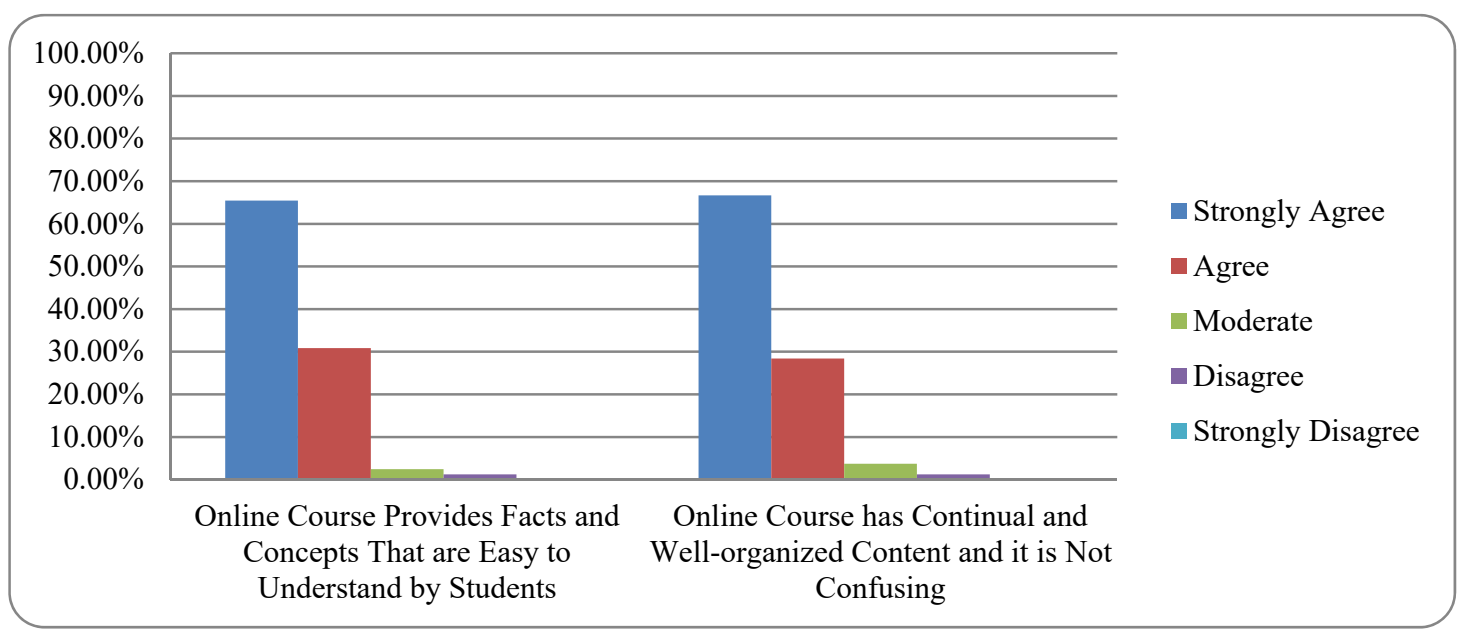

Figure 3. This online course contains this teaching interactivity for item 5 and item 6

Figure 3 shows two items, item 5 entitled this online course provides facts and concepts that are easy to understand by students and item 6 is that this online course has continual and well-organized content and it is not confusing. For items 1, a total of 53 students $(65.43 \%)$ strongly agree and 25 students $(30.86 \%)$ agreed. Meanwhile, no student strongly disagrees and 1 student $(1.23 \%)$ disagrees. A total of 2 students $(2.47 \%)$ who pressed the moderate button. In total, many students support that online courses are very easy to understand though they have facts. Therefore, it shows that the teaching system used is very good. However, emphasis should be placed on weak students by giving a more concise way of remembering facts.

Furthermore, there are item 6 which is this online course that has a continual, well-organized and misleading content indicating that a total of 54 students $(66.67 \%)$ strongly agree and $23(28.40 \%)$ students agree with this 
statement. Next, no student presses the strongly disagree button but 1 student $(1.23 \%)$ pressed the disagree button. Meanwhile, 3 students $(3.70 \%)$ answered moderate. Strictly, the content that has been compiled and taught has a good continuity to give understanding to many students. Therefore, students will understand the well-taught subjects more. However, this should be further reviewed so that coordination can be made to give an understanding to the students.

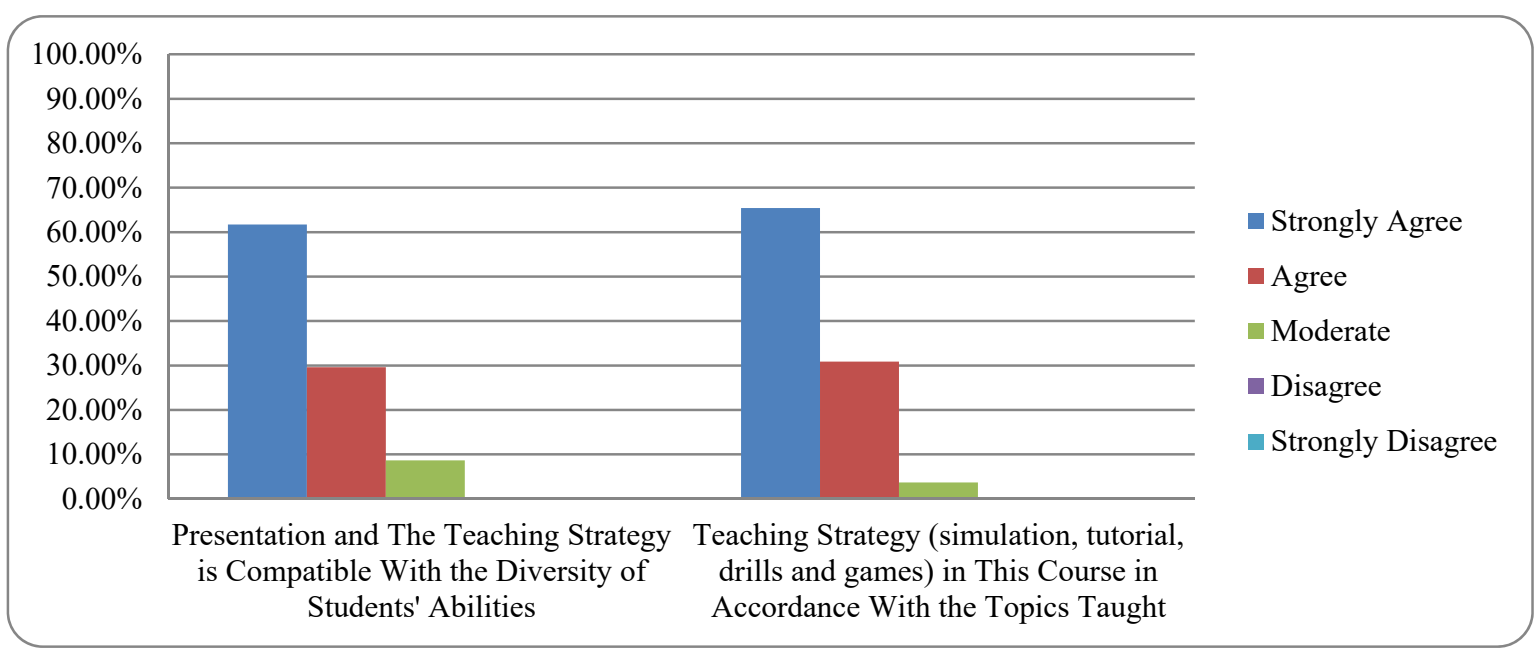

Figure 4. This online course contains this teaching interactivity for item 7 and item 8

Figure 4 shows two different items, item 7 is presentation and the teaching strategy is compatible with the diversity of students' abilities and item 8 is the teaching strategy (simulation, tutorial, drills and games) in this course in accordance with the topics taught. For items 7 , a total of 50 students $(61.73 \%)$ were strongly agreed and 24 students $(29.63 \%)$ agreed. Meanwhile, no student pushes the buttons strongly disagree and disagree. For moderate, a total of 7 students $(8.64 \%)$ pressed the button. In conclusion, all students give a positive outlook on this matter. It can be seen that the students liked the way the instructors teach. This has a positive impact on the students because they have different advantages.

Similarly for item 8, teaching strategies (simulations, tutorials, training exercises and games) in this course are in line with the topics taught which shows that 53 students $(65.43 \%)$ are strongly agree and 25 students $(30.86 \%)$ agree with the question. Meanwhile, no student presses the buttons strongly disagree and disagree. A total of 3 students $(3.70 \%)$ pressed the moderate button. Ultimately, the teaching strategies used are very good and received positive feedback from the students. This is great for improving student excellence in this subject. Therefore, this momentum should be maintained so that students can fully utilize the knowledge contained in this subject.

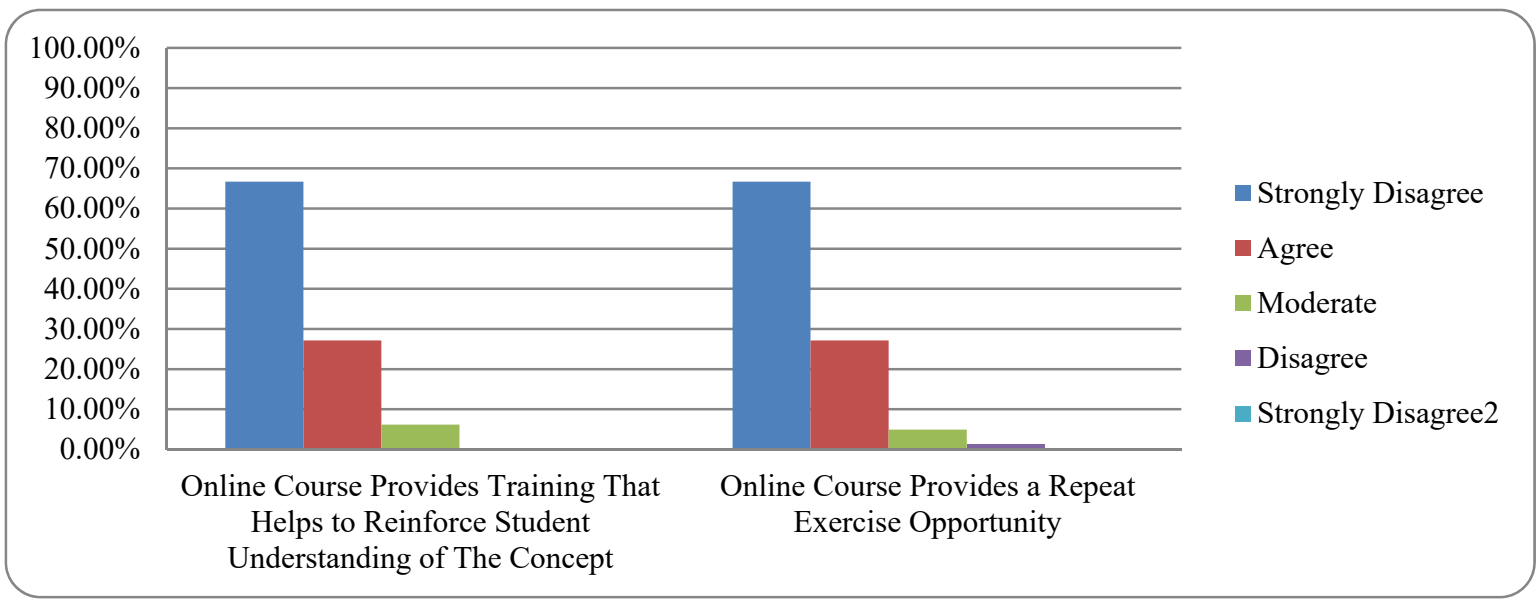

Figure 5. This online course contains this teaching interactivity for item 9 and item 10

Figure 5 shows two different items, item 9 is this online course provides training that helps to reinforce student understanding of the concept and item 10 is this online course provides a repeat exercise opportunity. For items 9 , 54 students $(66.67 \%)$ strongly agreed and 22 students $(27.16 \%)$ agreed. Meanwhile, no one presses the button to strongly disagree and disagree. For moderate, 5 students $(6.17 \%)$. It is clear that this item received a positive 
response from the students. Exercises provided will provide a greater understanding to students in this field. Therefore, those who are good at playing a role that can positively impact them to advance in this field.

Item 10, this online course provides an opportunity to repeat exercises, indicating that $54(66.67 \%)$ students strongly agree and 22 students $(27.16 \%)$ agree with this statement. In addition, for strongly disagree, no one pressed this button and 1 student $(1.23 \%)$ pressed the disagree button. Meanwhile, a total of 4 students $(4.94 \%)$ pressed the moderate button. Therefore, the results indicate the students support on having the opportunity to be able to repeat answering the questions given. Because of that they are able to remember the input better. However, improvements in terms of facilitating the given questions need to be emphasized so that students who find it difficult to understand the question can answer it easily.

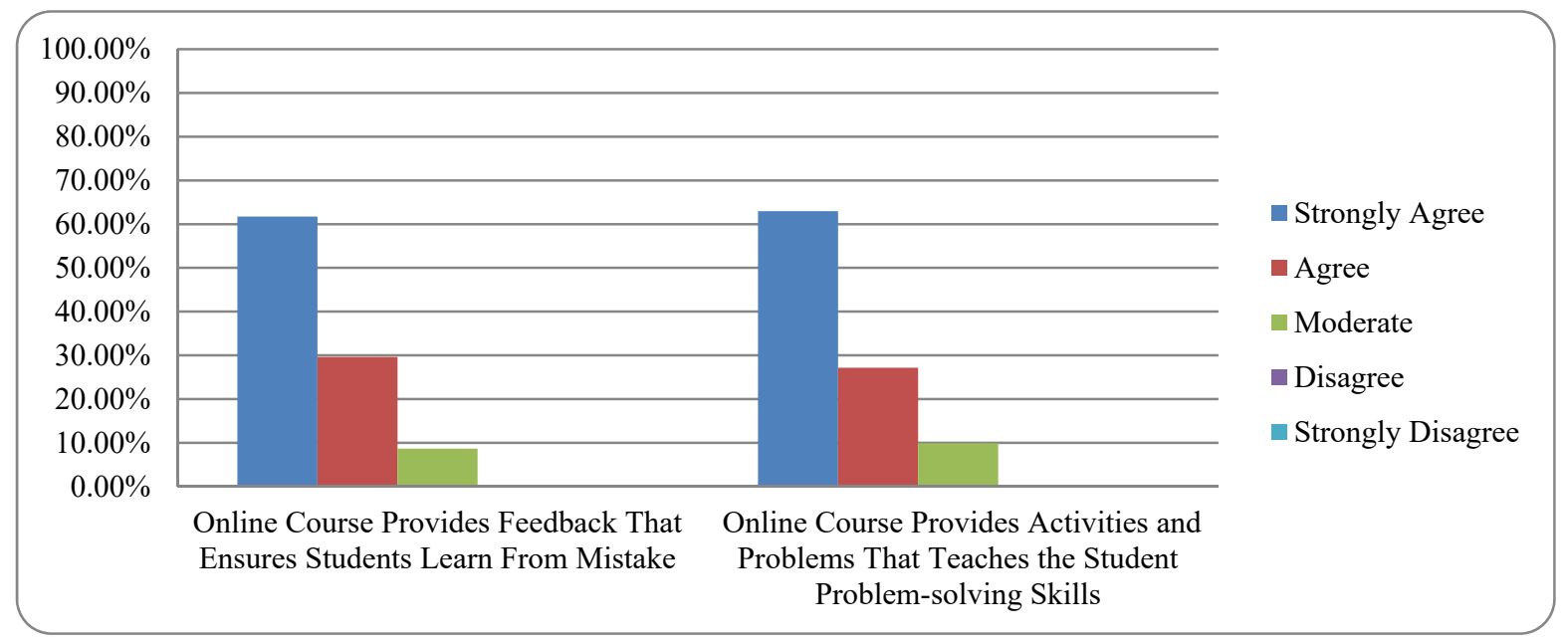

Figure 6. This online course contains this teaching interactivity for item 11 and item 12

Figure 6 shows two different items, item 11 is this online course provides feedback that ensures students learn from mistake and item 12 is this online course provides activities and problems that teaches the student problem-solving skills. Item 11 shows 50 students (61.73\%) strongly agree and 24 students $(29.63 \%)$ agree with this statement. No student who presses these buttons to strongly disagree and disagree. Meanwhile, for moderate, 7 students $(8.64 \%)$ pressed this button. This online lesson obviously opens the eyes of students to work better. This is because with the feedback form students will be more aware of their weaknesses. They agree with this item 6 to make it easier for them to know their own lessons performance.

For item 12, this online course provides activities and problems that teach students the problem solving skills, indicating that a total of 51 students (62.96\%) strongly agree and 22 students $(27.16 \%)$ agree with this statement. Additionally, no student presses these buttons to strongly disagree and disagree. Meanwhile, for moderate, there are 8 students $(9.88 \%)$. Hence, students are very happy to be able to solve their own problems. This is because it is not easy to solve problems that rise because it requires creative and critical thinking. Additionally, students support this activity as it strengthens their spirit to solve any problems encountered in learning.

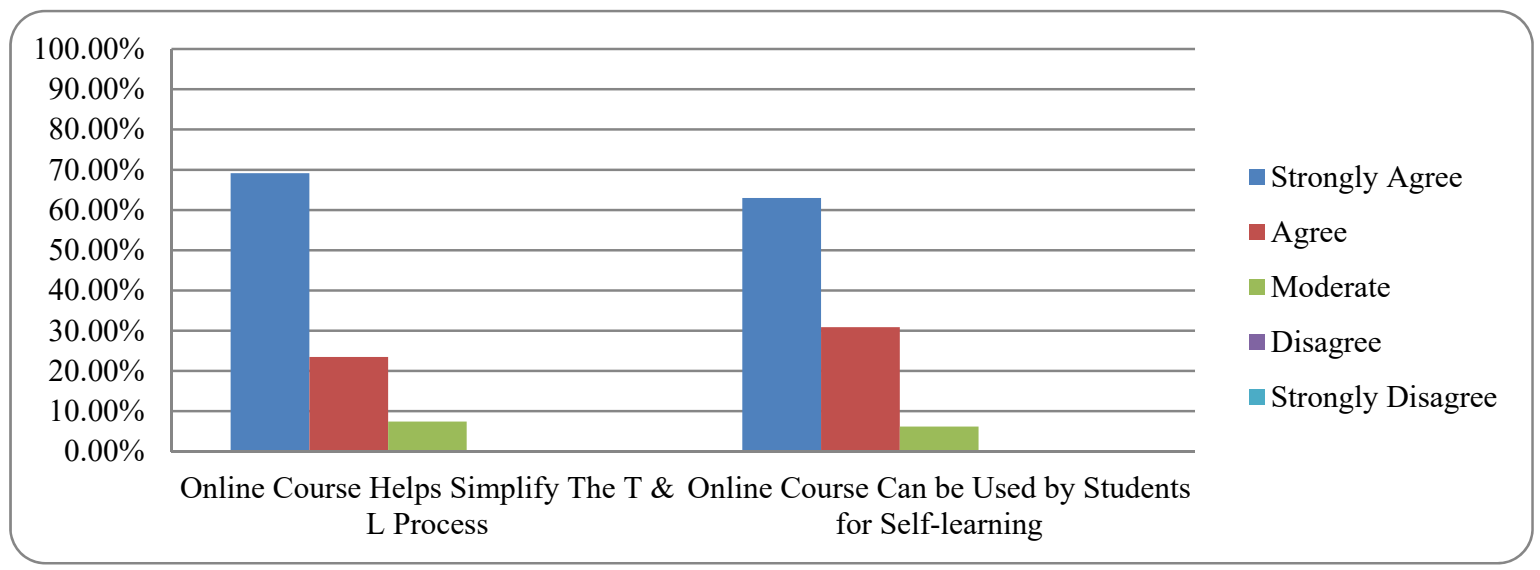

Figure 7. This online course contains this teaching interactivity for item 13 and item 14 
Figure 7 has 2 separate items; item 13 is this online course helps simplify the T \& L process and item 14 is this online course can be used by students for self-learning. For item 13, the students who strongly agree are 56 students $(69.14 \%)$ and agree to 19 students $(23.46 \%)$. No student pushes these buttons to strongly disagree and disagree. Meanwhile, moderate were 6 students $(7.41 \%)$. Because of that, this course will enable students to access and they will be able to study anywhere. Therefore, the T \& L process takes place quickly and easily. This is especially favored by students as they feel it saves them time especially for working students.

Item 14 is this online course that can be used by students for self-directed learning. A total of 51 students (62.96\%) strongly agreed and 25 students (30.86\%) agreed with this statement. Meanwhile, no student presses these buttons for strongly disagree and disagree. For moderate, it shows 5 students $(6.15 \%)$ who pressed this button. It is clear that this course benefits many students as it can be seen that students support online learning. This gives students the opportunity to carry out their own self-learning or group work. This can improve the student's quality of online learning.

\section{Discussion}

Overall, the result that can be made based on the analysis of data is that items that have high numbers are strongly agreed, agree and moderate buttons. However, the votes for disagree button are flat and no votes are made for strongly disagree button. This analysis shows that item 13, this online course helps facilitate the teaching and learning process ( $\mathrm{T} \& \mathrm{~L}$ ) to have the most options for strongly agree buttons which is as many as 56 students equal to $69.14 \%$. In addition, for item 1 , this online course provides syllabus that are in line with the curriculum formulated by the Ministry of Education, which is 49 students equivalent to $60.49 \%$ for the agree button. The high percentages of strongly agree and agree buttons are supported from Normaliza Abd Rahim (2014) and Arif Budi Winarto \& Sri Handayaningsih (2013), stating that with the use of multimedia as a tool for teaching aids has facilitated students' understanding. In addition, the repeatedly use of this material has facilitated students to remember what they have learned. Furthermore, the results of this study are similar to the study conducted by Andri Samsul Rizal, Munawar Rahmat \& Ahmad Shamsu Rizal (2016) where the learning process will be more interesting and interactive. The teaching time is much shorter and systematic to ensure that the time spent outside can be used as best as possible.

On the other hand, the strongly disagree button is not showing any amount as no votes are made for this button. However, for the disagree button there is also an equality of votes of 1 student equal to $1.23 \%$, for the 5 items titled this online course provides teaching content to meet the stated objectives, this online course provides the content of the lessons related to student's existing knowledge of, this online course provides facts and concepts that students can easily understand, this online course has continual and well-organized content and it is not confusing and this online course provides an opportunity to repeat exercises. This is supported by Joko Susilo, Sri Anitah and Sri Yamtinah (2017), who argue that the content of the teaching materials and goals to be achieved while teaching encourage students to learn. Therefore, there are some features that allow students to enjoy learning activities that are importance, interests, fairness, relevance and so on. It can therefore be concluded that the student who pressed this button was a student who is likely to not achieve the goals they want and lack of interest in the subject. The last one is for the moderate buttons, one item of item 12 with the highest score of 8 people, equivalent to $9.88 \%$ titled this online course providing activities and problems that teach students the problem solving skills. Most students pressed the moderate button because they still do not understand the subject taught. According to Azman Fadzil (2015), during an observation in a subject, students ask teachers to repeat the topic or thing they do not understand. This is because they have been influenced by the surroundings and are not focused on learning which causes the understanding and reasoning process to be slower It is also possible that students will repeat this with frequent rates that make them choose to press the moderate button. Therefore, they push this button so teachers are aware of their weaknesses and change the way they teach.

The conclusion can be made that these online course items help facilitate the $\mathrm{T} \& \mathrm{~L}$ process have the most votes for strongly agree buttons as most students have time constraints. Therefore, online learning gives them the opportunity to learn anywhere. It also helps students who are busy to find the right time to review lessons especially for students who are working and have side jobs. This will allow students to learn and earn their own income without sacrificing their education. In addition, Mohd Hamdan Haji Adnan (2017), Normaliza Abd Rahim, Nik Rafidah Nik Muhammad Affendi \& Awang Azman Awang Pawi (2017) and Normaliza Abd Rahim \& Nik Ismail Harun (2016) said that the developed world now requires humans to move fast to ensure the rapid development of technology that can generate fast and sophisticated information and communication. This development is crucial to ensure Malaysia moves in parallel with other countries. 
Online course items that provide the syllabus in line with the curriculum formulated by the Ministry of Education Malaysia show that many agree with this statement as this online lesson is a lesson maintained and has some rules that the subject's founder must adhere to. Therefore, the founders or instructors need to obtain appropriate inputs and comply with the regulations issued by MOE to the university. Thus, this online course is very suitable for all students who are still studying in Malaysia and it is indeed fulfilling the guidelines from the MOE. Furthermore, the votes made to disagree also indicate the equation of the votes for the item titled this online course provides teaching content to meet the stated objectives, this online course provides the content of the lessons related to the students existing knowledge, this online course provides facts and concepts that are easily understood by students, this online course has continual and well-organized content and is not confusing and this online course provides an opportunity to repeat exercises. This is because, it is likely that the student is a very weak student, less interested and not willing to learn this subject through online. Therefore, the student needs to change his mind as to achieve the same excellence as other friends. On the other hand, teachers can reduce benchmarking for students so that students who are relatively weak in certain subjects can follow the lesson until they quickly understand the lesson. This is supported by Laili Farhana Md Ibharim, Maizatul Hayati Mohamad Yatim and Md Nasir Masran (2015) which states that one will have their own goal when they need to be sharpened to ensure technology-oriented skills and learning.

These online course items provide activities and problems that teach students the problem solving skills to have the highest votes for moderate. This is most likely because the capabilities of an individual are different to solve a problem. Therefore, it is very difficult for them to understand the right way to solve the problems that they faced. They need to think creatively and critically to find a suitable solution for the problems faced so that the problem does not become more complicated. As a result, every problem is likely to finish successfully or worse. So they choose to press moderate to vote based on the experience they face. This is in line with Jamilah Hamid, Nor Hasbiah Ubaidullah \& Aslina Saad (2014) opinion, stating that technology requires a wide range of interactivity modes and various forms of exercises. The use of virtual applications requires a variety of good and effective multimedia technologies (Noraien Mansor \& Normaliza Abd Rahim, 2017e), (Normaliza Abd Rahim, Awang Azman Awang Pawi \& Nik Rafidah Nik Muhammad Affendi, 2018). Khairul Nizam Mohd Khalid, Nik Mohd Rahimi Nik Yusuf and Nurul Hana Ab Nasir (2014) stated that in order to ensure that the subject continues to be utilized efficiently, internet skills are needed to ensure interaction and interactivity are accurate and have new inputs. New teaching materials can be made to ensure students benefit from this new technology.

In conclusion, the results of this study benefited students and lecturers as they were able to take this input as a study material in future research. Additionally, the study materials that have been studied will provide the benefit to students and lecturers to obtain the latest findings in their research. So they can make a new study to ensure that research on online learning is getting stronger and growing in today's globalization. In addition, the results of this study are also expected to benefit the website builder to create a site that provides benefits to the students. This is because, in today's times, we see too many dumps of gossip sites. Therefore, they need to change their mind to bring the youth together to strengthen their knowledge by acquiring knowledge online. With the increasingly sophisticated broadband facility now, we need to be given enough benefits so that we can become a youth with great knowledge. In this context, the Ministry of Higher Education (MOE) can also benefit from the results of this research as it can be used as a guide to the KPT to ensure that this online learning can be used for all students in the country. Other than that, it can also reduce student learning gaps in urban and rural areas. This is a very good thing for MOE to further strengthen the learning system through this online learning. It is hoped that future research will focus on how best to overcome the weakness of students in a subject simply by using online learning. This should be given attention and effort not only to the students but also to the instructors so these groups will not continue to drop out.

\section{References}

Abdullah, N., Yusuf, N. A. N., Noh, N. M., \& Zabit, M. N. M. (2017). Pembinaan Perisian Interaktif untuk Menerapkan Kemahiran Proses Sains dalam Mata Pelajaran Sains Sekolah Rendah. Jurnal Pendidikan Sains \& Matematik Malaysia, 7(1), 1-17.

Adnan, M. H. H. (2017). Perlakuan Pengguna Penjawat Awam Sabah dan Penggunaan Internet. Jurnal Komunikasi Borneo, 5, 1-24.

Armanda, R. (2015). Analisis Faktor Penerimaan dan Penggunaan Teknologi dalam Sistem Informasi Akuntansi dengan Pendekatan TAM. Jurnal Ilmu \& Riset Akuntansi, 4(3), 1-21.

Ayob, A. (2017). Kesan Pembelajaran Menerusi Penggunaan Bahan Bacaan Interakti Berasaskan Laman Web Terhadap Kefahaman Membaca Kanak-Kanak. Jurnal Pendidikan Awal Kanak-Kanak, 6, 1-17. 
Fadzil, A. (2015). Penggunaan Aplikasi Multimedia Interaktif Dalam Kemahiran Melukis, Mewarna dan Menganimasi Secara Digital. Universiti Putra Malaysia.

Fatmawati, E. (2015). Technology Acceptance Model (TAM) untuk Menganalisis Penerimaan Terhadap Sistem Informasi Perpustakaan. Jurnal IqraI, 9(1), 1-13.

Gardner, H. (2003). Multiple Intelligence After Twenty Years. Chicago: American Educational Research Association. https://doi.org/10.1111/j.1467-9620.2004.00312.x

Hamid, J., Ubaidullah, N. H., \& Saad, A. (2014). Aplikasi Realiti Maya Desktop Bukan Immersif: Teknologi Terkini dalam Domain Pendidikan. Journal of ICT in Education, 1(1), 103-110. https://doi.org/10.1109/ICDIPC.2015.7322997

Ibharim, L. F. M., Yatim, M. H. M., \& Masran, M. N. (2015). Menerokai Kemahiran Abad Ke-21 Kanak-Kanak dalam Proses Reka Bentuk Permainan Penceritaan Digital. EDUCATUM - Journal of Science, Mathematics and Technology, 2(1), 82-96. https://doi.org/10.13140/RG.2.1.1491.3360

Kaur, S., Wei, G. W., \& Gee, K. P. (2018). Redesigning Massive Open Online. Courses (MOOCs) Based on Lecturers'Perception. https://doi.org/10.1007/978-981-10-4223-2_3

Khalid, K. N. M., Yusuf, N. M. R. N., \& Nasir, N. H. A. (2014). Persepsi Pelajar Diploma Pelancongan Politeknik Ibrahim Sultan Terhadap Pengajian Bahasa Arab Komunikasi (Aa 303) Melalui "Youtube". International Journal of Islamic Studies and Arabic Language Education (IJISAE), 1(1), 1-9.

Mansor, N., \& Rahim, N. A. (2017a). Written Discourse in Digital Audio Folklore. Man in India, 97(2), 491-499.

Mansor, N., \& Rahim, N. A. (2017b). Implicature in Students' Perception towards Language Learning. Man In India, 97(2), 329-336. https://doi.org/10.21462/ijefll.v2i2.42

Mansor, N., \& Rahim, N. A. (2017c). Digital Written Discourse. Man in India, 97(20), 115-124.

Mansor, N., \& Rahim, N. A. (2017d). Instagram in ESL classroom. Man in India, 97(20), 107-114.

Mansor, N., \& Rahim, N. A. (2017e). Boom! with Social Media. Universiti Malaysia Terengganu: Penerbit Universiti Malaysia Terengganu.

Mulyani, A., \& Kurniadi, D. (2015). Analisis Penerimaan Teknologi Student Information Terminal (S-It) dengan Menggunakan Technology Acceptance Model (TAM). Jurnal Wawasan Ilmiah, Manajemen dan Teknik Informatika, 7(12), 112-125.

Rahim, N. A. (2013). Literature Computer Program among Primary School Learners. TOJET: The Turkish Online Journal of Educational Technology, 12(2), 193-199.

Rahim, N. A. (2014). The Nearly Forgotten Malay Folklore: Shall We Start With The Software? TOJET: The Turkish Online Journal of Educational Technology, 13(3), 216-221.

Rahim, N. A., \& Harun, N. I. (2016). Students' Perception towards Malay Folklore Songs. Springer Science and Business Media Singapore 2016 Regional Conference on Science, Technology and Social Sciences (RCSTSS 2014) (pp. 641-648). https://doi.org/10.1007/978-981-10-1458-1_59

Rahim, N. A., Pawi, A. A. A., \& Affendi, N. R. N. M. (2018). Integration of Values and Culture in Malay Folklore Animation. Pertanika J. Soc. Sci. \& Humanities, 26(1), 359-374.

Rahim, N. Abd., Affendi, N. R. N. M., \& Pawi, A. A. A. (2017). Dissemination of Values and Culture through the E-Folklore. The Turkish Online Journal of Educational Technology, 16(1), 32-36.

Rizal, A. S., Rahmat, M., \& Rizal, A. S. (2016). Efektivitas Multimedia Interaktif Flash Pada Pembelajaran Pendidikan Agama Islam di Sekolah Menengah Pertama. Jurnal Pendidikan Agama Islam - Ta'lim, 14(2), 165-183.

Saad, A., \& Daud, E. D. (2016). Kepelbagaian Model Penerimaan Teknologi dan Sistem Maklumat. International Conference on ICT in Education 2016. Universiti Pendidikan Sultan Idris.

Salsidu, S. Z., Azman, M. N. A., \& Abdullah, M. S. (2017). Tren Pembelajaran Menggunakan Multimedia Interaktif dalam Bidang Pendidikan Teknikal: Satu Sorotan Literatur. Sains Humanika, 1(5), 135-141. https://doi.org/10.11113/sh.v9n1-5.1187

Sayekti, F., \& Putarta. P. (2016). Penerapan Technology Acceptance Model (TAM) dalam Pengujian Model Penerimaan Sistem Informasi Keuangan Daerah. Jurnal Manajemen Teori dan Terapan, 9(3), 196-209. https://doi.org/10.20473/jmtt.V9I3.\%25p 
Siregar, K. R. (2011). Kajian Mengenai Penerimaan Teknologi dan Informasi Menggunakan Technology Accaptance Model (TAM). Rekayasa, 4(1), 1-7.

Susilo, J., Anitah, S., \& Yamtinah, S. (2017). Pengembangan Media Pembelajaran Virtual dan Interaktif untuk Mensimulasikan Instalasi Jaringan Listrik di SMK 2 Surakarta. Dlm. Prosiding Nasional 7, Seminar Pendidikan Nasional "Pemanfaatan Smartphone untuk Literasi Produktif Menjadi Guru Hebat Dengan Smartphone". Pascasarjana Teknologi Pendidikan, Universitas Sebelas Maret.

Widiatmika, A. A., \& Indra, D. (2018). Pengembangan Model Penerimaan Teknologi Internet oleh Pelajar dengan Menggunakan Konsep Technology Acceptance Model (TAM). Jurnal Sistem Informasi MTI-UI, 4(2), 81-92. https://doi.org/10.21609/jsi.v4i2.249

Winarto, A. B., \& Handayaningsih, S. (2013). Media Pembelajaran Jaringan Saraf Tiruan Metode Hopfield Berbasis Multimedia. Jurnal Sarjana Teknik Informatika, 1(1), 1-8. https://doi.org/10.12928/jstie.v1i1.2542

\section{Copyrights}

Copyright for this article is retained by the author(s), with first publication rights granted to the journal.

This is an open-access article distributed under the terms and conditions of the Creative Commons Attribution license (http://creativecommons.org/licenses/by/4.0/). 